\title{
The land: Primary category of faith ${ }^{1}$
}

\author{
G J Volschenk (Pongola) \\ Research Associate: Department of New Testament Studies \\ University of Pretoria
}

\begin{abstract}
This review article of Walter Brueggemann's book "The land: Place as gift, promise, and challenge in biblical faith" (2002) mainly focuses on land as the primary category of faith in the Bible. The main focus is on the dialectical interrelationship between land possession and land-loss. A holistic, systemic and triangular interrelationship exists between God, land, Israel and Torah/covenant. The balance in this triangular relationship is essential for equilibrium in the system. The pendulum thus swings between land, exile and kingdom or in other words, between "landedness" and "landlessness". The conclusion is that ignorance of this holistic and triangular interrelationship is of great cost and peril to any generation's perspective on land.
\end{abstract}

\section{INTRODUCTION}

Brueggemann (2002) shows the importance of land in the Bible, as well as its importance in the 21st century (see Volschenk 2001:163-164 for a critique with regard to methodological issues in Brueggemann). The book's main focus is that land is the primary category of biblical faith.

Brueggemann (2002:xiii) explores important theological trends that have an immense influence on and practical implications for the study of land.

- $\quad$ The Hebrew term eres refers to both "earth" and "land" and the interrelationship between earth and land is stressed. It is not possible to discern the exact meaning in a specific context. According to Israel eres thus refers to all land.

\footnotetext{
${ }^{1}$ Review Article: Brueggemann, W 2002. The land: Place as gift, promise, and challenge in biblical faith. Minneapolis, MN: Fortress Press. Dr G J Volschenk participates as research associate in the project "Biblical Theology and Hermeneutics", directed by Prof Dr Andries G van Aarde, Faculty of Theology, University of Pretoria.
} 
- The second theme is that the claim of "promised land" in the Old Testament represents a vigorous ideological assertion on a large political scale. Brueggemann concludes that land entitlement leads to earth occupation. He describes two modern day examples where the ongoing ideological force (and cost) of the claim of the "promised land" leads to violence. The first concerns the territorial ambitions of the state of Israel that lead to unrestrained violence against the Palestinian people. The second example is that the same ideology of entitlement has in a derivative way served the Western powers grounded in this broad ideological claim and which have used this claim as a rationale for the colonization of other parts of the earth. According to Brueggemann, Western colonization takes place under the guise of an entitlement rooted in this biblical tradition. The reader or interpreter must be aware of the danger of anachronism and ethnocentrism in the application of the ideology of the "promised land".

- L Land-care goes hand in hand with this "ideology of land promise". Two dimensions of "land theology" are of particular contemporary importance. Firstly, the care or the abuse of the land or creation is generally recognized as a biblical and theological concern. It is not possible to claim a direct awareness of "environment" based on the Bible tradition, for such a claim is clearly anachronistic. But landcare is an inherent element of land theology, especially in relation to the Biblical Jubilee. Secondly, the crisis of agribusiness is of particular concern, because land-care and land-management are transposed into a commodity without any human dimension or interrelationship with God or the Torah. The problem is created by the collusion of commercialization of farming and the family farm or subsistence farming (see Brueggemann 2002:xix-xx). These two dimensions are directly related to the dialectic of land possession and land-loss.

- The next important issue is the interrelationship of God, land, Israel and the Torah/covenant. This important interrelationship is structured in a triangular manner (see Volschenk 2001:180). 


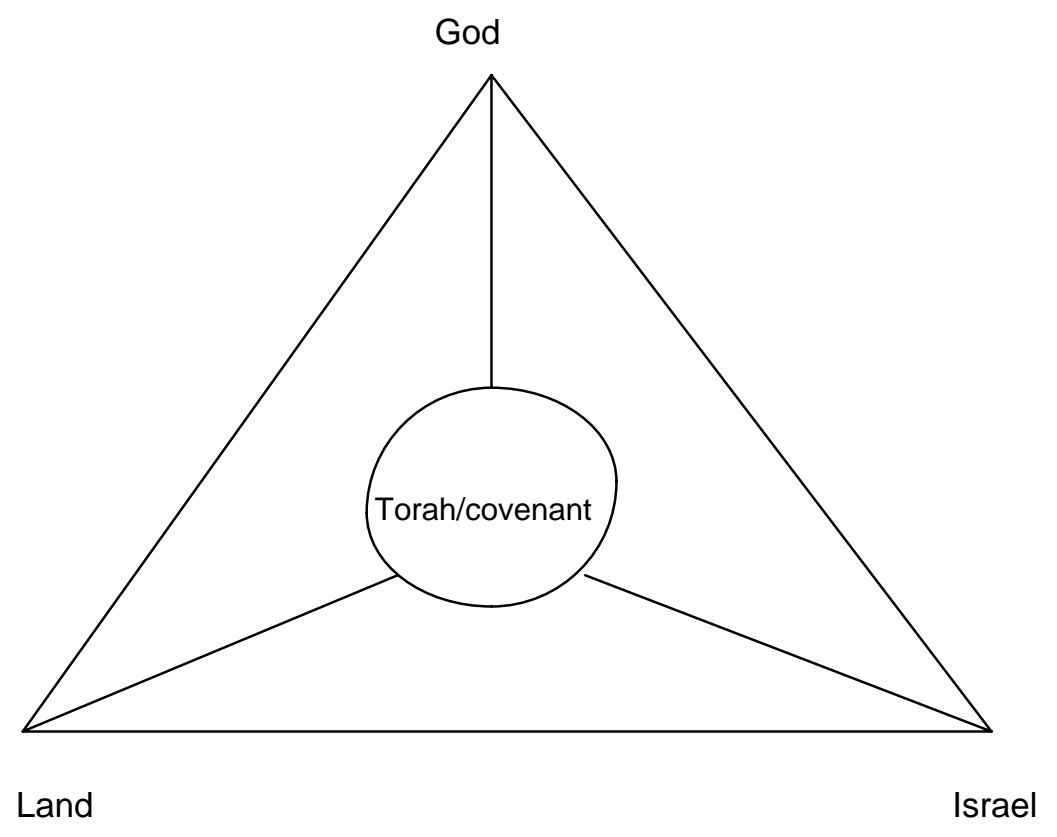

Brueggemann (2002:xvi-xviii) mentions the importance of the connection between land possession and Torah obedience, but fails to recognize the interrelationship of all the elements of the triangle, namely God, land, Israel and Torah/covenant. He recognizes the importance of the interrelationship of these elements with regard to contemporary (postmodern - GV) land issues.

The review article will follow the structure of the "movement of history" according to Brueggemann (2002:xxv), namely land, exile and kingdom. The literature of the Bible suggests the movement according to the three phases in Biblical history.

\section{LAND}

Chapters 1-5 in Brueggemann's book (2002) describe the dialectic between land possession and land-loss according to the promise/fulfillment scheme.

\subsection{Dialectic interrelationship between "landedness" and "landlessness"}

The primary focus of Brueggemann's argument is the dialectic between "landedness" and "landlessness". According to Brueggeman "land" may have a dual meaning. Firstly, land refers to actual earthly turf and secondly, it has a symbolic meaning. The symbolic meaning expresses the wholeness of joy and well being characterized by social coherence and personal ease in prosperity, security, and freedom. Biblical as well as contemporary use of the term "land" moves back and forth between literal and symbolic intentions. 


\title{
The land: Primary category of faith
}

There is a constant dialectic movement between the literal and the symbolic sense of the term. The symbolic sense confirms the social connotations of land that are derived from historical experience. The literal sense of the term will protect us from excessive spiritualization, whereas the historical sense will remind us of the real yearning or hunger for a place. The historical placement includes excess meanings both rooted in and moving beyond literalism (see Brueggemann 2002:2).

Brueggemann (2002:3) categorically states that land is the central theme of biblical faith. Land is a way of organizing biblical faith. This primary focus on land is in contrast with the existentialist interpretation or formulations of the mighty deeds of God in history of the 1970's. The contemporary concern is on the human need of place, rootedness and attachment to land. Land is glamorized around virtues of mobility, anonymity, freedom, and selfactualization. Thus, a fresh look at the Bible suggests that a sense of place is a primary category of faith. This is in contrast with Martens (1981:16-24) who argues that land is only one element of God's four point plan in the Bible. The main contemporary crisis is rootlessness and not meaninglessness.

Brueggemann (2002:4) describes the importance of place as follows:

\begin{abstract}
Place is space that has historical meanings, where some things have happened that are now remembered and that provide continuity and identity across generations. Place is space in which important words have been spoken that have established identity, defined vocation, and envisioned destiny. Place is space in which vows have been exchanged, promises have been made, and demands have been issued. Place is indeed a protest against the unpromising pursuit of space. It is a declaration that our humanness cannot be found in escape, detachment, absence of commitment, and undefined freedom.
\end{abstract}

It is of the utmost importance that land be understood as space with Yahweh. Biblical faith has to do with Yahweh, his people, his covenant, and his land (Brueggemann 2002:5). However, according to Volschenk (2001:180), it is a triangular interrelationship.

The Bible describes the relationship between God and Israel. Israel is a landless people whose whole history and life must be understood in terms of the hope for, and in response to the promise of land. Israel is the landless on the way to the Promised Land. As a landless people, yearning for land, Israel is presented by means of several images, namely as sojourners, wanderers (desert/wilderness experiences) and exiles (see Brueggemann 2002:5-8).

The "landlessness" of Israel exists in a dialectical interrelationship with "landedness"'. Israel had its moments of being in the land, controlling and 
celebrating and exploiting the land. Israel as landed people is the settlement in Egypt, Israel under the monarchy and the little community around Jerusalem under Ezra. The Bible is thus the story of God's people with God's land. It is a dialectic interrelationship between "landlessness" and "landedness". Brueggemann (2002:12) describes this interrelationship through the history of Israel in the Old Testament as follows: "And its destiny vis à vis the land is always on the move toward fulfillment: from promise to the security of slavery, from desert to the destructive power of kingship, from exile to the weariness of moral management".

\subsection{The promised land}

Brueggemann (2002:15-25) studied land-theology diachronically through the long, tortuous history of Israel. The long historical processes headed toward land, exile and kingdom, but it is neither a neat, nor strict historical scheme. The threefold pattern has grown out of the texts themselves. The historical scheme starts at Genesis. The book represents two histories, both concerned with land. The dialectic relationship between "landedness" and "landlessness" is very clear in Genesis 1-11 and in Genesis 12-50 respectively. Genesis 1-11 is about people fully rooted in land, living towards expulsion and loss of land. This history is about presuming upon the land and losing it as a result thereof. Genesis $12-50$ is about Abraham and his family who did not have land, but who were on the way towards it, living in confident expectation and anticipation thereof. According to Brueggemann (2002:15):

These two histories set the parameters of land theology in the Bible: presuming upon the land and being expelled from it; trusting toward a land not yet possessed, but empowered by anticipation of it; Our lives are set between expulsion and anticipation, of losing and expecting, of being uprooted and rerooted, of being dislocated because of impertinence and being relocated in trust. Clearly these stories are not remote from the contemporary experience of Western culture.

Brueggemann stresses that the history of anticipation and the history of expulsion alternate with each other, both in Biblical history and in contemporary history. The Bible focuses primarily upon anticipation and relocation. The Bible looks ahead with confident hope. The new history begins in a word spoken, the promise of God to Abraham (Gn 12, 15, 17). Land anticipating history begins with God who, through the speaking of God, makes all things new. God makes all things new when everything had become old and weary and hopeless. Creation begins anew, as a history of anticipation of 
the land. God makes the impossible possible. God is the God of creation and transformation (in a non-political connotation - GV). The contrast between "landedness" and "landlessness" can be tabulated as follows:

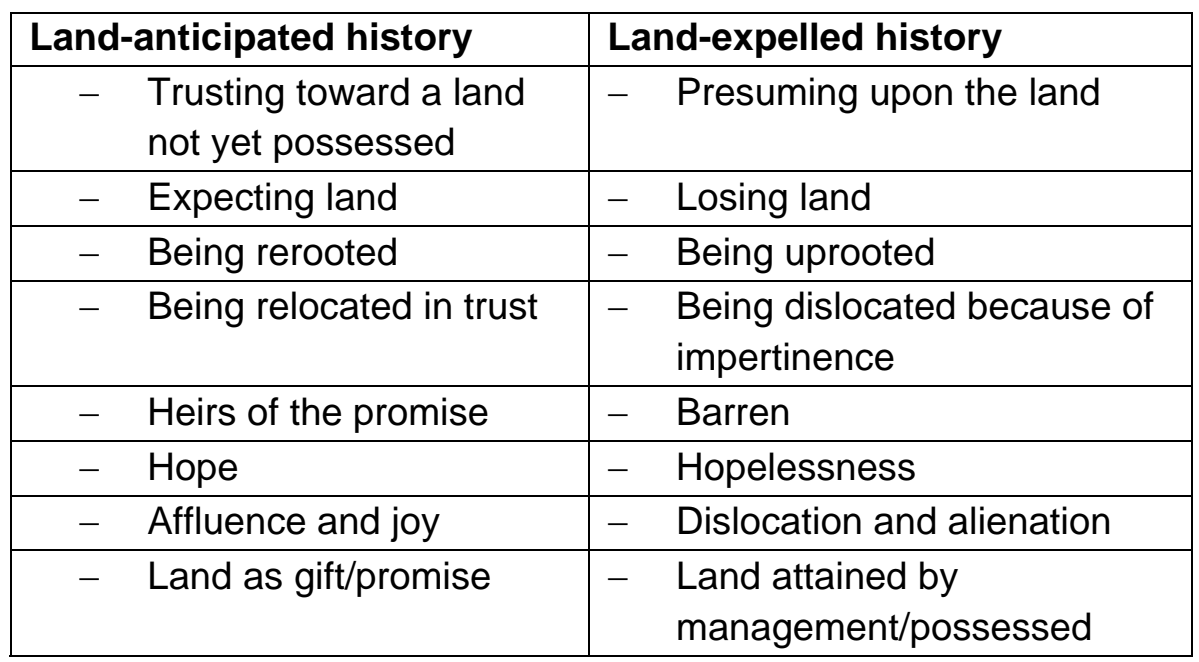

\section{3 "Landlessness" as wilderness}

The wilderness experience is Israel's worst radical memory of "landlessness" (Ex 16-18; Nm 10-14). The generation of the wilderness is characterized as recalcitrant and disobedient. Israel's experience of "landlessness" nearly destroys both itself and its faith. The literal sense of wilderness is that of a sandy place demanding more stamina. But the symbolic sense is of more theological importance. It symbolizes chaos, darkness, the formless, the lifeless, the landless and displacement. The history of the exodus can be summarized as follows: Israel is placed in conditions of barrenness and the promises are no longer valid. The people of the promises become the victims of the wilderness. "landlessness" erodes Israel's faith, yet they are called to be a people of faith in a situation of "landlessness".

The above-mentioned perspective is only one side of the coin. The other side is that despite the wilderness experience and "landlessness" of Israel, Yahweh is always present and Israel does not lack anything. Given this view, wilderness really is a contradictio in terminus. Yahweh is the Life-giver: in the wilderness God gives meat, bread and fullness. The life-giving resources do not come from land, but from Yahweh. Yahweh is the transformer of situations. It is about Yahweh's presence in the hiddenness of glory. God is also Lord over "landlessness". God gives life in fullness despite of or in contrast to "landlessness". Wilderness and Yahweh belong together. Yahweh is present in the wilderness. Yahweh's presence is sufficient for survival, it is graciously received and given on the basis of his trustworthiness. Brueggemann (2002:41) stresses Yahweh's presence and the fact that Israel 
is not lacking anything in the wilderness. Yahweh gives life in fullness and abundance to his people.

\section{4 "Landedness": From sojourners to land possessors}

The exodus-wilderness episode in the story of Israel has a happy ending in the fulfillment of the Promised Land. However, before entering the Promised Land reference is made to the pause at the Jordan. The boundary of the Jordan has a literal and a symbolic sense. The crossing of the Jordan is the radical transformation of a historical group: from "landlessness" to "landedness"; from sojourners to possessors; from slaves to heirs; from barrenness to life in abundance.

The promise of the land and the covenant of Yahweh with Israel are central to the land as gift. The intimate interrelationship between God, land, Israel and Torah/covenant is evident in the history of Israel. God speaks and Israel listens. In that speaking/hearing moment, a new Israel is called into being for the new time of the land. Israel is always in relationship with land and with Yahweh. It is a dialectical relationship. Israel plays the role of Yahweh's listening partner in the covenant; Yahweh is the life-giving Lord who promised the land. The land is the gift from God who gives life in abundance: water, food, bounty and minerals. Brueggemann (2002:49) warns against the interpretation of existentialism and the reduction of faith to a natural fertility religion. He also criticizes secular humanism which prefers to talk only of land and never of Yahweh. This is a very important critique against the land-reform programs in Africa, especially those in Zimbabwe and, to a lesser degree, those in South Africa too.

The land is also the land of temptation. Israel must remember that the land is a gift from Yahweh. Yahweh gives the land and life in abundance. Forgetting Yahweh is Israel's greatest temptation. This leads to the idea that the land contains in its own gifts, adequate means to secure existence. This goes hand in hand with self-seeking; the temptation to private well being and self-security.

The land as gift from Yahweh brings about responsibility for Israel. Central to land is the link with the Torah. Torah consists of guidelines for land management. Torah exists so that Israel will not forget who owns the land and it serves as a reminder of how it was given to them. The Torah focuses on three tasks, namely:

- $\quad$ to have no images that alienate us from history;

- $\quad$ to keep the Sabbath so that life is not coercive; 
- $\quad$ to honor or care for those covenant brothers and sisters who although they may not have power, have dignity (e g the poor, the stranger, the sojourner, widow, orphan and the Levite).

The land of promise is also a land of threat. The new land is bounteous and attractive. But the contradiction is that it is a land that creates fear and hopelessness, because it is unknown and full of other nations. Israel tried to avoid receiving the land because of fear. The land is only for those who sense its precariousness and who act in their vulnerability.

\subsection{Land-care}

The land must be taken care of. It must be managed, ordered, and administered. It must be used well, firstly in order not to lose it and secondly in order to enhance it. Israel is at the brink of the fulfillment of the promise. For Israel the Jordan represents the juncture between two histories. Central to this history is the promise-fulfillment scheme.

The first history is one of "landlessness" on the way to land. The land promised to Abraham via the covenant of God is taken into possession. Sojourners became heirs. The major demand of that history was to trust a promise. The second history of Israel is the history on the other side of the Jordan. It is the history of "landed Israel" in the process of losing the land. This is the history of secure settling and possession, but which ended in exile under king Johoiachin. This history is characterized by the demand for caring management of the land as being its major demand. According to Brueggemann (2002:68) the major temptation is to use up the land in wasteful, careless, self-indulgent ways and in so doing, to lose it. That is what happened to Israel: they yielded to the temptation and ended up in exile.

Two models of land management occurred. The first, of lesser importance is constituted by the judges who primarily engaged in crisis intervention. The second and more important form of land management occurred in the form of kingship. According to Brueggemann (2002:69) "king" refers on the one hand "to those who presided over the organized life of Israel and so had responsibility for the land", while on the other hand, it refers "in an impressionistic way to all people entrusted with the power and authority to choose social ends and deploy resources for those ends." Conditions for kingship in Israel were threefold:

- $\quad$ The king must be a brother of the covenant, and not a foreigner.

- $\quad$ The king must honor certain prohibitions, for example, he must not multiply for himself horses, wives, or silver and gold - all of which pertain to self-securement.

- The king's central activity is to read the Torah. 
Israel wants a king like the other nations. The form of land management by the king is the same as that of other nations, but the intent is totally different. The relationship between God, Israel and land is unique, hence the peculiar relationship between king and land. Other kings are inclined to control the land. In contrast, the king of Israel has to manage the land as a gift which, although entrusted to him, he never possesses. Thus, there is a choice between two alternatives: The king will be either (a) "like all the nations that are round about" or (b) "one from among your covenant partners". The first leads to slavery, alienation, and finally expulsion. The other way leads to solidarity and well-being. Israel must choose between the two possibilities, because it cannot be both ways.

\section{EXILE}

In chapters 6, 7 and 8 of his book, Brueggemann describes the history of the road to exile, starting with the kings. In Israel the kings are not free to manage the land as they wish to do. The intimate interrelationship between God, land, Israel and the Torah is still relevant for the dialectic of "landlessness" or "landedness" (triangular relationship - GV). The breaking of the relationship between Israel and the Torah leads to the disintegration of the triangular interrelationship. This means Israel's loss of land through exile.

\subsection{The land, the prophet, and the king}

The relationship between Israel and land is not to be perceived in the same way than what it would be among the nations. There is a peculiar relationship between Israel and land, namely the triangular interrelationship between God, land, Israel and Torah/covenant. The prophet is the additional component in the apparatus of managing the land in Israel. The prophet's function is to secure the triangular relationship. The prophet, in contrast to the king, continually asserts those dimensions of governance and land management that kings prefer to disregard. The question is: (a) whether royal land management will acknowledge the prophetic dimensions of land perception and (b) whether land will be lost by kings who silence or disregard prophets (see Brueggemann 2002:85).

There is thus an intimate relationship between land, prophet and king. Three elements show the importance of the prophet as constitutive of Israel's understanding of her new situation in the land.

- $\quad$ The prophet is precisely for the time in the land (see Dt 18:9-15). "The land creates a situation in which the new decisive word of Yahweh must be made visible to Israel" (Brueggemann 2002:86); 
- $\quad$ Prophets are intended to address kings. It is because of kings that prophets appear;

- $\quad$ The gift of the prophet in Israel stands in contrast to the temptation of the land, namely magical practices of self-securing and manipulations.

The place and function of the prophet can thus be summarized as speech:

- $\quad$ in the land;

- $\quad$ in the face of the king; and

- $\quad$ against adulterous forms of self-securing.

The people demanded a king like all the other nations, but in contrast to that a prophet was raised up by Yahweh.

\subsection{Conflicting views on land}

Conflicting views on land exist in the history of the kings in Israel (see $1 \mathrm{Ki}$ 21). According to the popular view of the kings they owned the land as their possession and as a tradable commodity. In contrast to this view, land is a gift from God, is inherited and is therefore an inalienable inheritance. The latter is also known as the covenantal view of land. This view accentuates the triangular interrelationship of God, land, Israel and the Torah/covenant. Brueggemann (2002:87-92) describes the conflicting views on land with reference to the narrative of Naboth, Ahab and Jezebel in 1 Kings 21.

According to Brueggemann (2002:94) the history of Israel in its classical period is presented as a tension between royally secured land and covenanted precarious land. It is evident that exile follows self-indulgent consumerism (see, e g, Amos; $1 \mathrm{Ki} 21$ etc). The curse is that land managed outside the covenant will be lost (see Dt 28:63-68). The kings were landmanagers entrusted with the responsibility to care for the land, but they were the very instruments of land-loss (see Hos 2).

The biggest cause of land-loss came about as a result of forgetting forgetting that the land was gifted-land through Yahweh's covenant. The land caused amnesia - Israel forgot Yahweh and his demands. The kings were not able to see the bigger picture of the destiny of Israel's history. The prophets on the other hand, the partners and challengers of kings, knew which way Israel was heading to - exile. The prophets discern what kings cannot see and articulate what kings cannot bear (see Jeremiah). Thus the kings stubbornly steered towards "landlessness", homelessness and exile. 
Jeremiah understands land as inheritance from Yahweh. "He understands the covenantal dimension of landholding, the fact that being in land and possessing it, depends on continual reference to Yahweh" (see Brueggemann 2002:111, 112). Jeremiah presents land-loss as pollution and harlotry (see Hosea). "The land is polluted in that it has become impure by covenant breaking and violation of the relation with Yahweh". Harlotry was the result of Israel ceasing to trust the land-giver and engaging in alternative ways of securing its own existence.

\subsection{Yahweh's transformation - the new history}

The words of Jeremiah are subtle and dialectical. They are dialectical because landholding is an act of disobedience (see Nm 14:39-45) and landloss is an act of faith. The words are the curious transformation of "landlessness" to announce that land-loss is the way of faith to the new land. Exile is thus the way to a new life in the new land. This represents a radical understanding of history. This is the history of reversal and transformation. The exiles are the real heirs. Those who cling to the land are the ultimate exiles. The focus or attention of Yahweh is on the exiles and resurrection to new life; not on land or return to land. The primary principle is that of reversal: The outsiders or exiles are those who belong. The ones remaining in the land are the ultimate cursed and destroyed ones (see Dt 28:37). The dying ones will be the bearers of life. "Newness comes in discontinuity to those who have no claim. It is among exiles that Yahweh calls into existence things that do not exist (Rm 4:17)" (see Brueggemann 2002:117).

The new history too is grounded in the covenant formula: "And they shall be my people and I will be their God." To an even larger extent this new history vests with Yahweh. God takes new responsibility for history. Yahweh wills exile and land-loss; God however resolves that this special new history should take place among exiles.

The third history concerns continuity and discontinuity. The "landed people" want to hold on to continuities and believe that old forms will surely continue. The new history can only be described in the images or models of the old history and faith. On the other hand, the new history is also in discontinuity with the old history. The land is really lost, and history has really come to an end. There is no king, no temple, no royal city, no Israel. The new history is rooted in exile, the life called from death (see $\mathrm{Rm} 4: 17$ ). Therefore, the beginning of this third history, that is the history from exile to land, is radical and produced an enormous amount of literature (e g, Is, Lm, Ezk). It is reflective material, which in various ways considered the brutality of history ending and expressed amazement at history beginning again (see 
Brueggemann 2002:123, 124). This new history is rooted in the promise of Yahweh. In its "landlessness", hopelessness and abandonment, Israel may hope for a new history, one rooted in the character of God himself and in the fidelity of Yahweh.

God transforms the history of humankind. The relationship between God, land, Israel and Torah/covenant is also evident in the prophets. God transforms those who are displaced and homeless and provides a home for them and gives them land. Land is a gift freely given by God to undeserving exiles. God makes the impossible possible. God is the creator of the new history. God transforms the historical existence of the homeless and hopeless in exile. God's will for Israel goes against current circumstances. God promised Israel land and the promise will be fulfilled.

\section{KINGDOM}

This is the third part of history, moving from exile to land. The third history also includes the New Testament period through Jesus Christ, from "landlessness"/ crucifixion to "landedness"/resurrection. Chapter 9 describes the last part of the Old Testament history dealing with the return of the exiles to the land. Chapter 10 represents a brief discussion of land theology in the New Testament and chapter 11 describes the connection between land, fertility (women) and justice.

\subsection{From exile to land}

Yahweh's jealousy for Jerusalem/Zion is the primary message. Yahweh is holy, so the land and people must be holy or pure too. Within this context the purification and reconstruction under Ezra and Nehemiah can be understood best. The land can only be retained in terms of urgency, precariousness, and graciousness of the covenant. The land is unclean and must be purged. The purification of the land requires an alternative, separatist consciousness and the result is a new land under the covenant of the holy God. Three offences lead to an unclean land, namely intermarriage with non-Israelites, the nonhonoring of the Sabbath and the economic exploitation of the peasants by the elite through tax, debt and levies. The foundation of the above-mentioned disparity is the contrasting view on land and social ordering of the community. According to Brueggemann (2002:149) "the reform is not a desperate moment of parochialism but an attempt to order life, community, and land in covenantal ways and to avoid the Syro-Hittite alternative that denies Israel's holy destiny".

Brueggemann (2002:150-156) gives a brief description of the Hellenization process and its influence on Israel's perspective on land and social ordering. The central issue for Brueggemann is the conflict between the 
elite in the city and the rural peasants. The conclusion is that the Hellenization is a process in terms of which the uncaring rich take advantage of trusting, helpless poor. The Hellenistic world created a keen sense of alienation. The people of Israel are aliens in their own land. It is within this context that Israel hoped for and held on to the promise of land. This hope for transformed land, new land, renewed land, became a central point for an expectant Israel.

\subsection{Land as gift or grasp}

Davies (1974:396-404; cf Brueggemann 2002:160) concludes that in the history of Christianity "land" as central theme has been: (a) rejected, (b) spiritualized, (c) treated historically, and (d) presented sacramentally. According to Davies, the theme of land was displaced by the person of Jesus Christ. According to Brueggemann, the main principle regarding land in the New Testament is one of grasping it with courage on the one hand, while on the other waiting in confidence for the gift. Jesus and the Jesus movement appear to be a restatement of the theme of waiting in confidence for the gift.

The issue of land in the New Testament must be understood in a dialectical manner, namely land as a physical, historical way and land as a symbol. The New Testament perspective on land can be summarized as follows (see Brueggemann 2002:160-164):

- $\quad$ The center of the New Testament proclamation is the dynamic end of the old age/political-historical age and the coming of the new kingdom. The imagery stresses the discontinuity and the contrast between the two arrangements;

- $\quad$ The central image is the kingdom, that is, the kingdom of God and the kingdom of this world. The kingdom clearly includes the idea of the historical, political, physical realm that land is. The kingdom or coming of Jesus is understood with reference to the new land;

- The radical inversion or reversal of "landed"-"landlessness" is evidenced in the teaching of Jesus. Jesus confirms the idea of the gift of land;

- Jesus' actions are also to be understood as the return of the dispossessed to the land from which they had been driven. They are the first bearers of the promise. Jesus' ministry affirms that the land promise is still in effect.

- $\quad$ The crucifixion/resurrection echoes the dialectic of possessed land lost/exiles en route to the land of promise. Jesus embodies precisely that which Israel has learned about land, namely that being without land makes it possible to trust the promise thereof; while grasping land is a sure way of losing it. The "landed" are called to homelessness. The "landless" are given a new home (Brueggemann 2002:164). 
- $\quad$ There is conflict between the supporters of the old age of land arrangements and the defenders of the recipients of the new land. Thus the proclamation of Jesus is about graspers losing and those who are open to gifts, receiving.

The above short review on land theology in the New Testament by Brueggemann, is reductionist and simplistic. In the preface of the second edition, Brueggemann attempts to justify the second edition by referring to the methodological criticism against the first edition and the paradigm shifts that occurred in the time frame between the two editions. The methodological shortcomings in his research on land theology in the New Testament are very clear. Wright (1984, 1990; see Volschenk 2001:186-200) for example, gives a holistic perspective on the triangular interrelationship between God, land, Israel and Torah/covenant/family in the Old Testament and in the New Testament. This is a holistic perspective on land in contrast to Brueggemann's simplistic perspective. The use of the social-scientific model of the advanced agrarian society is a holistic perspective on the place and function of land in the ancient society. It is a holistic interpretation framework that avoids the fallacies of anachronism, ethnocentrism and reductionism (see Volschenk 2001:200-226).

\subsection{Land management in the Bible: God versus Freud and Marx!} According to Brueggemann (2002:173-177), there is an intimate connectedness between God, humankind (family - GV), land and covenant. Men and land are linked in a covenantal relationship. "The operating land ethic in our society denies that relationship at enormous cost not only to land but to our common humanity." The conclusion that we treat land in the way we treat women, is reached (the "we" in this instance equals males - GV). There is thus a direct interrelation between sexuality and fertility; between economics and justice. Economics cannot be separated from sexuality, nor can sexuality be separated from economics. A new land ethic requires a new sexual ethic, free from both promiscuity and domination. "Applied to land, we shall not have fertility until we have justice toward the land and toward those who depend on the land for life, which means all the brothers and sisters." It is within this context that Brueggemann (2002:177) links Freud and Marx: "They understood that modern civilization is grounded in an extraordinary selfdeception that distorts both sexuality and economics, and that ends in deep alienation from self, from neighbor, from land." Contemporary, isolated land reform programs ignore the systemic interrelationship between God, land, people and covenant at its own peril. Productivity requires attention to justice. 
Fertility causes us to rethink economics and sexuality raises questions of righteousness.

\section{CONCLUSION}

The movement of the history of the Bible is from land, to exile to kingdom. The dialectical interrelationship between "landedness" and "landlessness"; life and death; crucifixion and resurrection is the main principle of this history. There is a systemic, holistic and dialectical interrelationship between God, land, Israel and Torah/covenant/family. This is a triangular and dialectical interrelationship of the "landless" on the way to land and the "landed" in the process of losing the land. The conclusion is that the ignorance of the relationship with God or the transgression of the Torah/covenant/family leads to "landlessness", homelessness and eventually to death. Land is a primary category of faith and a promise from Yahweh. God initiated the covenant relationship between humankind and God self. The Torah is the principle and norm for a full life in the promised land. The Bible story is thus about the relationship of Yahweh with God's people in God's land. The primary focus in the New Testament is the contrast between grasping with courage or waiting in confidence for the gift. The fundamental issue thus is the holistic, dialectic and triangular interrelationship between God, land, Israel/people and Torah/covenant. The dysfunction or breaking of any one of the relationships is of great cost and to the peril of past, contemporary and future humankind.

\section{Works Consulted}

Brueggemann, W 2002. The land: Place as gift, promise, and challenge in biblical faith. Minneapolis, MI: Fortress Press.

Davies, W D 1974. The Gospel and the land: Early Christianity and Jewish territorial doctrine. Berkeley, CA: University of California Press.

Martens, E A 1981. The plot and purpose of the Old Testament. Leicester: InterVarsity Press.

Volschenk, G J 2001. Eksegeties-metodologiese vooronderstellings van die ondersoek na die ekonomie in die leefwêreld van Matteus: Toegepas op land, grondbesit en die jubilee. DD proefskrif, Universiteit van Pretoria.

Wright, C J H 1984. The use of the Bible in social ethics: Paradigms, Types and Eschatology. Transformation 1(4), 11-20

Wright, C J H 1990. God's people in God's land: Family, land, and property in the Old Testament. Grand Rapids, MI: Eerdmanns. 